\title{
The Effect of Auction Game on Students' Understanding of Simple Past Tense
}

\author{
M. Fadhly Farhy Abbas ${ }^{1}$, Risnawati $^{2}$, Destina Kasriyati ${ }^{3}$ \\ Universitas Lancang Kuning, Pekanbaru \\ E-mail: ${ }^{1}$ fadhly@unilak.ac.id \\ ${ }^{2}$ Risnaludal@gmail.com \\ 32destina@unilak.ac.id
}

\begin{abstract}
The aim of this research was to investigate the effect of auction game on students' understanding of simple past tense at the eighth grade of MTs. Jabal Nur Kandis. The population of this research was the second year students of MTs. Jabal Nur Kandis consisting of two classes which had 48 students. The sample of this research were VIII A (24 students) as experimental class 1 and VIII B (24 students) as experimental class 2 . The researchers applied auction game variation 1 in experimental class 1 while; in experimental class 2 the researcher applied auction game variation 2. The data was the students' scores in simple past tense taken from the post test. The data was analyzed by using Normality-test, Homogeneity-test, T-test and N-gain. After conducting this research, it was found that the result of n-gain average score in experimental class is 0.39. The Assimp.Sig (2-tailed) is 0.195 . So the hyphothesis $\mathrm{H}_{1}$ was accepted and $\mathrm{Ha}_{1}$ is rejected. With the Assimp.Sig (2-tailed) $>0.05$ it meant there was no any significant effect of the implementation of Auction game (variation 1 and variation 2) on students' understanding of simple past tense. In conclusion, there was no any significant effect of the implementation of auction Game on students understanding of simple past tense at the eighth grade of MTs. Jabal Nur Kandis. But, auction game can improve students' understanding on simple past tense.
\end{abstract}

Keywords: Auction Game, Simple Past Tense, Experimental Research

\section{INTRODUCTION}

Students who learn English usually have problem in understanding tenses especially simple past tense. We need to use a technique which is effective and more interesting in teaching grammar especially simple past tense. One of the techniques which could be used in teaching simple past tense is by using auction game. According to Shi ( 2012) based on his research auction is a fun way to help students review key points in grammar and sentence construction while having some good fun. The researcher will apply auction game in teaching simple past tense. it will help the students to write and understand tenses easier, and it is a fun activity that make students interested.

The problem of this research is students usually have problem in understanding tenses especially simple past tense, the limitation of this research focuses on finding out the effectiveness of auction game in teaching simple past tense at the eighth grade of Mts. Jabal 
Nur. And Research question of this research is "is there any significant effect on students understanding of simple past tense by using auction game (variation 1 and variation 2) in Mts. Jabal Nur Kandis in academic years 2018/2019?

The purpose of the research is to find out the differences between the students taught by Auction game variation 1 and the students taught by Auction game variation 2 in terms of simple past tense at the eighth grade of Mts. Jabal Nur Kandis in academic years 2018/2019.

\section{Review of the Related Findings}

The first study was conducted by Ignat (2013) at Athen Greek School of Bucharest, Romania with student aged 10-11 years old. on his study auction grammar is effective strategy for simple past tense homework correction . auction game have been tried in his classes which definitely worked and far more engaging. The student loved to make bids and tried to find if the sentences was correct or not and to correct the sentences if there was a mistake.

The second study was conducted by Shi (2012) at School of English for International Bussines, Guangdong University of foreign Studies, China. On his study auction grammar is an effective stategy for teaching simple past sentences structure, sentences of auction are enganging and interactive tools which bring a lot of fun to this course. This researcher showed the auction sentences to studentson Power Point (PPT) slide. From her research, students have higher motivation in attending this course than before and they simple enjoy the procces of English language.

The third study was conducted by Cheng, Liao,and Chang ( 2018) at National Engineering Research for ELearning, Central China Normal University, China, National Taipei University of Nursing and Health Sciences, Taiwan, and Department of human Development and Family Studies, National Taiwan Normal University, Taiwan. On their research auction game mechanism is applied to the procces of keyword selection in academic reading course. In this research auction game which are rarely adopted in education, provide student with opportunities to express thier ideas. Beside, in this research not only demonstrate students' improvement of summary writing, but also explore the reading problems of graduate student. Specifically, they may lack the abilities of stucture sentences analysis.

The fourth study was conducted by Rouf (2015) with the eighth B grade students of Mts. Maarif jumo Temanggung in academic years of 2015/2015. On this research the implementation of Auction Grammar Game is very good to be applied as teaching learning method on simple present tense in the classroom, students' mean scores pre cycle just 3.35 and after 2 cycle, student mean score rose to 5,59 until 8.1.

The fifth study is entitled Post Graduate Certificate of Education Student Teachers' Views of economics Games as an Interactive Classroom Technique by Vussy A.N konyane' and Micheal M.Van Wyk (2015) from 
Department of Curriculum and Instructional Studies, School for Teacher Education, College of Education. This research is an experimental design. In this research, researcher's stated that paying games in the classroom does not solve all educational challenges, but games and simulation are useful and effective tools to actively involve Post Graduate Certificate of Education Student teachers in their learning. This was an opportunity to venture into more effective and efficient strategies to develop students' cognitive, psychomotor and affective learning skills.

After comparing the previous research, the difference of this research are the first research focus from the data and the analysis found by the researcher about game on for simple past tense homework correction. The second research focus on teaching simple past sentences structure, sentences of auction are enganging and interactive tools which bring a lot of fun to this course. This researcher showed the auction sentences to studentson Power Point ( PPT ) slide. The third research focus on auction game mechanism applied to the procces of keyword selection in academic reading course. The fourth research was focus on teaching learning method on simple present tense in the classroom. The last research concluded that auction game develops students' cognitive, psychomotor and affective learning skills.

\section{METHOD}

This research was experimental research. An experimental research was the most powerful quantitative research method for establishing cause and affect relationships between two or more variables (Meredith D. Gall 2007). It was categorized as a quasi-experimental research design. The researcher conducted this research in the difference classes (experimental class 1 and experimental class 2). The researcher taught the simple past tense in two classes (VIII-A as an experimental class 1 and VIII-B as experimental class 2). Experiment class 2 would be taught by using auction game variation 1 and Experiment class would be taught by using auction variation 2 .

This research was conducted in the class VIII A as experimental class 1 and class VIII B as experimental class 2 of MTs JABAL NUR Kandis. It was carried out on 1- 20 April 2019. This research was conducted for three weeks in six meetings and the auction game variation 1 used in the experimental class 1 and auction game variation 2 used in experimental class 2 .

According to Creswell (2012: 145) population is the group of individuals having one characteristic that distinguishes them from other groups. The population of this research was the eighth grade student of Mts. Jabal Nur Kandis Academic Year 2018/2019. They consisted of 2 classes and total number of the student is 48 .

In this research, the researcher used the test as research instrument. The test used in pre-test and post-test in getting the data. It would be true-false test. The 
instruction was students must write (T) for chosen correct answer and (F) for chosen incorrect answer.

The researcher tried out the test at eight grades of MTs Ar-Rahman Kandis on March 2019, which was consisted of 50 questions and 20 samples then, the reliability of whole items. The aim of try out was to determine the test validity, reliability and to find the index if difficulties of each items.

The data was analyzed statically to know the result whether it is statically significant or not between experimental class 1and experimental class 2 by using auction game. It was analyzed by using T-test for hypothesis test if it was normal and homogeneous, and using U-MannWhitney -Test if the data were not normal and homogeneous. The result data was calculated to get the average score.

To analyze the data of pre-test and post-test, the researchers used Software Statistical Package for Social Science (SPSS) for windows 21.0 before hypothesis test, first, the researcher did the normality test distribution data and homogeneity variance data for both classes. Testing normality distribution data in this research was done using test Kolmogorov Smirnov (KS-21) in program SPSS version 21.0, while Levene Test for testing homogeneity of sample. After normality and homogeneity test, the result data later was calculated to get the average of the score. The researcher used N-Gain between pre-test and post-test.

\section{FINDING AND DISCUSSION}

This chapter would like to present research finding dealing with the data which have been collected during the research by giving pre-test and posttest for the experimental class 1 and experimental class 2 of the eighth grade students at Mts. JABAL NUR Kandis. Furthermore, the data of pre-test and post-test were analysed by SPSS 21.0 in order to know the differences of students' grammar understanding of simple past tense which had been taught by auction game variation 1 and variation 2 .

a. The Result of The Research

a.) Result of Pre-Test

In this sub chapter, the researcher showed that the result of the students' score in pre-test. Before doing the treatment, the researcher gave a pre-test to the students. It was done to know basic ability of students in past tense. In this pre-test, the researcher did in first meeting. The students were given the true false questions by the researcher. It was done in experimental class 1and experimental 2.

The mean score of pre-test in experimental class 1 was 63,16 with the minimum score in pretest was 48 and the maximum score was 72. Meanwhile, the mean score of experimental class 2 was 63 with the minimum score was 48 and the maximum score was 72. Based on the mean score above, it can be summarized that the basic knowledge of experimental class 2 was lower than the experimental class 1 . 
The increase of the students' pretest score between experimental class 1 and experimental class 2 can be seen in the following diagram;

\section{Diagram 1. The Improvement of Pre-test Score in Experimental and Experimental class 2}

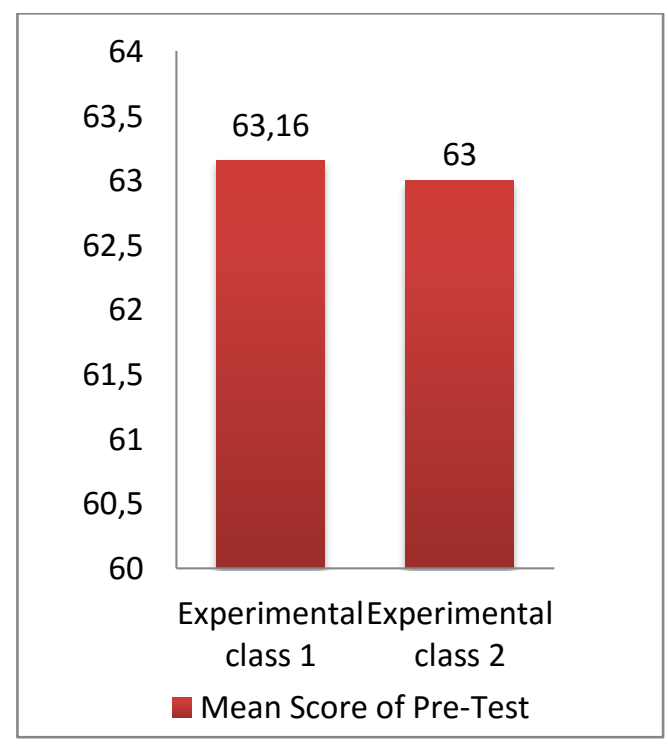

From the Diagram 1 above, it can be seen that the mean score of students' Pre-test of both classes. It can be analysed that the mean score of the experimental class 1 was higher than the experimental class 2 . It means that the basic knowledge of the students in experimental class 1 was good than experimental class 2 .

After calculating the mean score of the students in pre-test and post-test, the researcher continued to calculate the normality test and homogeneity test of data. The purpose to calculate those tests were to know whether distribution data was normal or not, and to know whether the data was homogenous or not. Those tests were important, because those results of data are used to support the hypothesis test. The significant number in pretest was 0.081 . Furthermore, the significant number was higher than significance $\alpha 0.05$. It means that the distribution data of pre-test in experimental class 1 and experimental class 2 was normal.

Secondly, the researcher did the homogeneity test by using levene test formula in SPSS. Homogeneity test was conducted to determine homogeneity sample. Thus, it was analyzed by comparing value of based on trimmed mean with the level significant level 0.05 . The result of homogeneity in experimental class 1 and experimental class 2 . It can be summarized that the data was homogenous. It can be seen in the comparison between trimmed mean score with significant $\alpha$. The significance of trimmed mean was higher than significant, $0.877>0.05$. it means that the data of pre-test score in experimental class 1 and experimental class 2 were homogeneous.

b.) Result of Post Test

After did the pre-test to know the basic knowledge of the students, the researchers do the treatments by applying auction game. The researchers did the treatments for six meetings. In experimental class 1 , the students were taught by auction game variation 1 in understanding simple past tense and the researchers taught auction game variation 2 in experimental class 2 . After the researchers did treatments in few meetings, the researchers gave posttest to the students in order to know the effect of using auction game towards 
grammar understanding especially in simple past tense.

The mean score of post-test in experimental class 1 was 75,67 with the minimun score was 72 and the maximum score was 92 . While, the mean score of experimental class 2 was 77,17 with the minimum score was 64 and the maximum score was 96. In line with the statement before, it can be summarized that the post-test score of experimental class 1 was lower than experimental class 2.

To know the students' increase between both of classes, it can be seen in the following diagram.

\section{Diagram 2. The Increase of Post Test Score in Experimental class 1 and Experimental class 2}

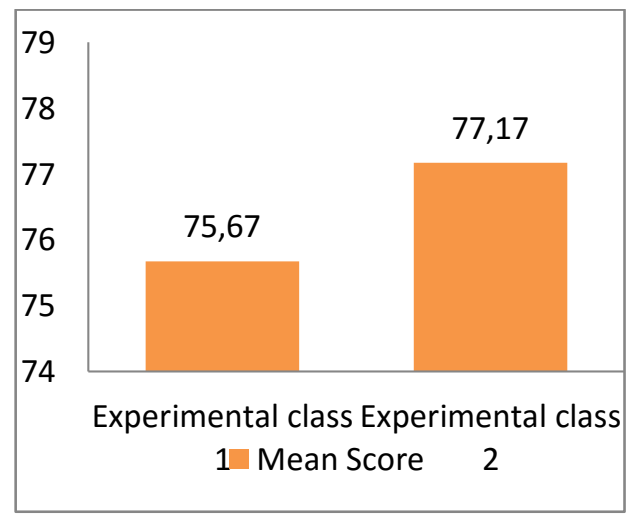

From the Diagram 2 above, it can be seen the post-test score of experimental class 1 was lower than experimental class 2 . The comparison of the score was 75,67 $<77,17$ It means that the auction game variation 2 had the effect towards students' simple past tense understanding. Furthermore, the researchers supported the data by using several test to know the normality data, homogeneity, and the significant difference of the test. The result of the test can be described in following points below;

(a) Normality Test

Normality test is a test to measure whether our data has normal distribution or not. Normal distribution is a symmetrical, bell-shaped distribution of data that has specific properties and is used as a reference point for comparing the shapes of data distribution. A test is called normal if the result indicate that few numbers of participants are at the right and left tails and most of participants are in the middle. It shows the symmetrical and one cluster of the data in the middle. To investigate the normality testing, the researchers use Kolmogorov-Smirnov test by using SPSS 21.0 program.

The data distribution was normal. It was proven by the significant number of the test. The significant number in Post test was 0.350. Furthermore, the significant number was higher than significance 0.05 . It means that the distribution data of post-test in experimental class 1 and experimental class 2 was normal.

(b) Homogeneity Test

Homogeneity test is applied to a single categorical variable from two or more different populations. It is used to determine whether frequency counts are distributed identically across different populations. In this research, the researchers tested the homogeneity data by using levene test in SPSS 21.0. The result of homogeneity, the data was homogenous. It can be seen in the comparison between trimmed mean 
score with significant. The significance of trimmed mean was higher than significant, $0.660>0.05$. it means that the data of post test score in experimental class 1 and experimental class 2 were homogeneous.

(c) T-Test

In line with the analyze data above, the data could be calculated by using nonparametric to know there is different significant or not between Auction Game towards reading understanding. The researchers calculated the data by using parametric statistic (T-test). So, this test done to know whether the data had different significant or not. T-test focused on Assimp.Sig (2-tailed) that was compared with significant level $(\alpha=0.05)$. If the data Assimp.Sig (2-tailed) $<0.05$, so the data was significant. But if the data Assimp.Sig (2-tailed) $>0.05$ it was unsignificant. The result of T-test of pretest of both was the Asymp.sig (2-tailed) was 0.195 . It was higher than significant level (0.05). It means that $0.195>0.05$. It can be concluded that there was no significant effect between experimental class 1 and experimental class 2 .

\section{a. N-Gain}

To know the effect of treatment that was given to experimental class 1 and experimental class 2 , the researchers used $\mathrm{N}$-Gain score. Before calculating $\mathrm{N}-$ Gain of pre-test and post-test both of classes, the researchers calculated the Gain score of pre-test and post-test of experimental class 1 and experimental class 2 diagram below:
Diagram 3. The difference of Average Score Both of Classes

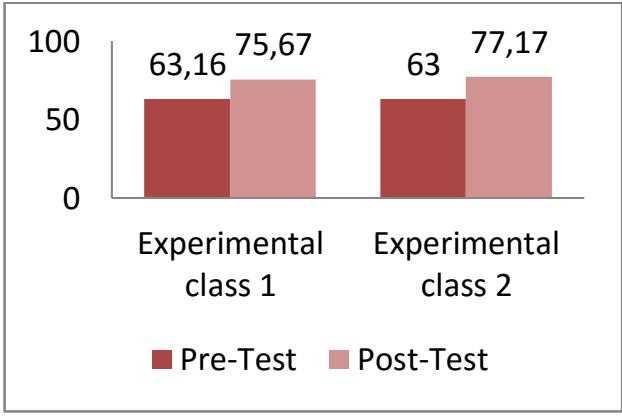

The Diagram 3 above clarifies that experimental class 1 students were influenced by auction game variation 1 . And experimental class 2 students were influenced by auction game variation 2 .

\section{b. Hypothesis Testing}

In this research used T- Test for hyphothesis testing, the hypothesis of this research as follow:

a) If Assimp.Sig (2-tailed) $>0.05$ it was unsignificant. Null Hyphothesis $\left(\mathrm{HO}_{1}\right)$ was rejected. It means there is no any significant effect of the implementation of Auction game (variation 1 and variation 2) on student's understanding of simple past tense.

b) If the data Assimp.Sig (2-tailed) < 0.05, Null Hyphothesis $\left(\mathrm{Ha}_{1}\right)$ was accepted. It means there is any significant effect of the implementation of (variation 1 and variation 2) on students' understanding of simple past tense.

Based on hypothesis testing by used T-Test the Assimp.Sig (2-tailed) was 0.195 . so the hyphothesis $\mathrm{HO}_{1}$ was 
accepted and $\mathrm{Ha}_{1}$ was rejected. With the Assimp.Sig (2-tailed) > 0.05 it means there is no significant effect of the implementation of Auction game (variation 1 and variation 2) on student's understanding of simple past tense.

The finding of this research that in term of class experiment class 1 with the pretest mean score was 63.16, mean posttest score was 75,67 and term of class experimental class 2 with the mean pretest score 63.00 , mean posttest score was 77,17 . Based on the score both of class, auction game variation and variation 2 was not effective but it could improve students understanding of simple past tense.

\section{Discussion}

Based on the findings, the researchers can be proved that the strategy was insignificant for the students in grammar understanding especially simple past tense. Based on the data, there was an increase in score of pre-test and post-test in experimental class 1 and experimental class 2 . The mean score of pretest in experimental class 1 was 63,16 and mean score of posttest was 75,67 . Then the mean score of pretest in exprerimental class 2 was 63 and mean score of posttest was 77,17. But, on hyphothesis testing has been obtained the Assimp.Sig (2-tailed) in TTest of Post test experimental class 1 and experimental class 2 score. The Assimp.Sig (2-tailed) was 0.195. so the hyphothesis $\mathrm{HO}_{1}$ was accepted and $\mathrm{Ha}_{1}$ was rejected. With the Assimp.Sig (2tailed) $>0.05$ it means there was no significant effect of the implementation of Auction game ( variation 1 and variation 2) on student's understanding of simple past tense

In this research, the researcher applied the strategy in the treatments. The researchers divided the students into groups, gave the auction sentences, to bid and buy the correct sentences on the whiteboard related to the simple past tense. Based on the result of the students' score, the researcher can describe the students' difficulties in answering the questions after given the treatments. Because some students did not come to the class during the treatment applied and experiment class 1 and experiment class 2 taught by the same teacher who applied the steps of auction game well.

Actually, there are five indicators in the questions. They were declarative sentences, interrogative sentences, nominal sentences, singular and plular. The students were easy to answer the questions related to simple declarative sentences. And, the students were difficult to answer the question related to the singular and plural subject.

As clarified previously, Ignat (2013) Auction game is a fun way to help students review grammar and sentence construction while having some good fun. Basically, students in small groups are given some 'money' with which to bid on various sentences. These sentences include correct and incorrect sentences; the group which 'buys' the most correct sentences wins the game.

This result of this research was in line with another researcher that has been mentioned in the previous chapter. One of them was research conducted by 
Khasanah (2016), in this research the researcher investigate "Improving The Students' Ability in teaching simple present tense Text By using Five auction game with the eighth B grade students of Mts. Maarif jumo Temanggung in academic years of 2015/2016. He found the significant student's grammar mastery in simple present tense and their involvement in English class could be improved by auction game. From the result of the analysis of the research, this game was effective for the students especially in grammar simple past tense. It was proven by the students' activity in answering the questions. This strategy directed the student to know the structure of the simple past tense. It made the students were easy to identify the error of the sentences. Furthermore, the students were interested in teaching and learning process. It was also proven by the increase of the students score in each meeting. Thus, it can be summarized that the strategy was effective for students' grammar mastery.

\section{CONCLUSION}

Based on the purpose of this research which is to identify the students who received in class instruction of auction game in teaching simple past tense variation 1 had different score than students who received in class auction grammar 2 at the eighth grade students at Mts JABAL NUR Kandis. And the formulation "Do the auction game variation 1 and variation 2 with the eighth grader of Mts. Jabal Nur Kandis in academic years 2018/2019?" It has been successfully answered that "no, they don't". It could be seen from the data presented in the previous chapter, there are several points that can be forwarded for the conclusion of this research relate to the eight grade students at Mts JABAL NUR in teaching simple past tense. Further, the conclusion could be down as follows:

There was no any significant effect of implementation auction game variation 1 and variation 2 towards students' understanding of simple past tense of the eight grade students at Mts JABAL NUR. It could be seen from the hyphothesis testing between post-test of experimental class 1 and experimental class 2. The Assimp.Sig (2-tailed) was 0.195 . so the hyphothesis $\mathrm{HO}_{1}$ was accepted and $\mathrm{Ha}_{1}$ was rejected. With the Assimp.Sig (2-tailed) > 0.05 it means there was no significant effect of the implementation of Auction game ( variation 1 and variation 2) on student's understanding of simple past tense.

This research that in term of class experiment class 1 with the pretest mean score was 63.16 , mean posttest score was 75,67 and term of class experimental class 2 with the mean pretest score 63.00 , mean posttest score was 77,17 . Based on the score both of class, auction game variation and variation 2 was not effective but it could improve students understanding of simple past tense.

Based on the result of the study, researcher would like to give some suggestion as follows:

a. Teacher must apply the steps auction game in teaching simple past tense well in the next class. 
b. Students should do more exercises about simple past tense, so students will get high score.

d. wants to compare the effectiveness of imperative in education and another field.

e. This research is useful for reader who interest in imperative sentence or wants to review this research

\section{REFERENCES}

Creswell, Jhon W. 2012. Educational Research: Planning, Conducting, and Evaluating Quantitative and Qualitativve Research. Newyork: Pearson Education

Cheng, H. N. H.,Liao, C. C. Y.,\& Chang, W.-C. (2018). iAbstract: Game-Driven Keyword Auction and Summarization for Academic Reading. Educational Technology \& Society, 21 (4), 248-258. c. This research is opened to be extended by the next researcher who

Ignat, Carmen. 2013. Effective Stategis or homework correction in EFL Class. JoLIE (6): 113.

Ignat, Carmen. 2013. Effective Strategies for Homework Correction in Efl Classes Athens Greek School of Bucharest, Romania.

Meredith. 2007. Educational Research: An Introduction ( $8^{\text {th }}$ Edition). Retrived on 15 March, 2018 from: https://www.amazon.com/Educ ational Research Gall/02054884.

Rouf, 2015. Improving Students' Understanding On Simple Present Tense Through Auction Grammar Game. Temanggung: walisongo university.

Shi, Jing. 2012. The Aplication Of Constructivism : Activities For Enliveling Comprehensive English Class. English Lnguage Teaching. 2 ( 6 ): 68 . 